\title{
Intraocular Lens Implant Device
}

National Cancer Institute

\section{Source}

National Cancer Institute. Intraocular Lens Implant Device. NCI Thesaurus. Code C49999.

A corrective lens that is designed to be implanted within the eye capsule to replace the natural lens. 